\title{
In vitro propagation of Kaempferia Galanga (zingiberaceae) and comparison of larvicidal activity and phytochemical identities of rhizomes of tissue cultured and naturally grown plants
}

\begin{abstract}
Vegetative propagation of $K$. galanga Linn (Zingiberaceae) cannot fulfill the current demand for planting material and tissue culture offers an alternative means for mass propagation. Experiments were carried out on propagation of plants through direct organogenesis and comparison of larvicidal activity and phytochemicals present in rhizome of natural and tissue cultured plants in order to confirm the potential use of tissue cultured plants as an alternative to natural plants in commercial scale productions. In vitro shoot induction was optimized with rhizome bud explants grown on MS medium supplemented with $2.0 \mathrm{mg} / \mathrm{L}$ Benzyl amino purine (BAP) and $0.5 \mathrm{mg} / \mathrm{L}$ IAA (Indole-3-acetic acid). MS medium supplement with $1.0 \mathrm{mg} / \mathrm{L}$ IAA and $0.2 \mathrm{mg} / \mathrm{L}$ Indol-3-butric acid (IBA) was identified as the best medium for root induction. Rooted plantlets were acclimatized successfully $(100 \%)$ in a mixture of soil: sand: compost $(1: 1: 1)$. Hexane found to be a better solvent for extraction of phytochemicals over methanol and the $50 \%$ hexane extract showed the highest larvicidal activity against the fourth instar larvae of $A$. aegypti. GC-MS analysis revealed the existence of the nine key compounds in both samples tested confirming the possibility of using tissue cultured plants as a substitute for natural plants in medicinal purposes.
\end{abstract}

Volume 2 Issue 4 - 2017

\author{
Senarath RMUS,' Karunarathna BMAC, ${ }^{2}$ \\ Senarath WTPSK, ${ }^{2}$ Jimmy GC $^{3}$ \\ 'Department of Medicine, Virgen Milagrosa University \\ Foundation, Philippines \\ 2Department of Botany, University of Sri Jayewardenepura, Sri \\ Lanka \\ ${ }^{3}$ Commission of Higher Education, Philippines
}

Correspondence: Senarath,WTPSK, Department of Botany, University of Sri Jayewardenepura, Nugegoda Colombo, Sri Lanka,Tel947I8136014, Email wtpsk201 I@yahoo.com

Received: February 02, 2017 | Published: March 20, 2017

Keywords: bioassay, conservation, tissue culture, GC-MS, k. galanga

Abbreviations: BAP, benzyl amino purine; IBA, indol-3-butric acid; IAA, indole-3-acetic acid; MS, murashige and skoog; RDB, randomized block design; EMC, ethyl p-methoxy cinnamate

\section{Introduction}

Kaempferia galanga Linn (Zingiberaceae) is distributed mainly in South East Asia and China ${ }^{1}$ and considered as a main ingredient of many traditional Ayurvedic drug preparations. ${ }^{2}$ Essential oil in rhizome is volatile and is used as a spice, beverage and also in perfume and cosmetic industries., ${ }^{3,4}$ Leaves and flowers contain flavonoids. ${ }^{5}$ Main constituents of the rhizome extract contain ethylp-methoxycinnamate, ethyl cinnamate, 3-carene, camphene, borneol, cineol, kaempferol and kaempferide which are responsible for many properties of $K$. galangal. ${ }^{3}$ The rhizome of the plant has been reported to possess stimulant, carminative, diuretic and stomachic properties. ${ }^{6}$ $K$. galanga also has biological activities such as antibacterial, antimicrobial, anticancer, larvicidal, amebicidal and pharmacological activities such as vasorelaxant and anti-inflammatory properties. ${ }^{7}$ The plant has been over exploited and listed under threatened category in Sri Lanka and India and in many other Asian countries. Therefore developing tissue culture techniques for mass propagation of $K$. galanga would be useful in conservation of this important medicinal plant. Evaluating the potential use of extracts from natural plants and tissue cultured plants on insecticidal activity would be beneficial in using tissue cultured plants as an alternative for natural plants. On the other hand, there is an increasing concern over the use of mosquito coils or vaporizers among general public in which they have a belief that the vapor/smoke from those has ability to cause cancers. As a preliminary study, use of powdered rhizomes of both natural and tissue cultured plants of $K$. galanga as a potential mosquito repellent has also been evaluated in the present study. There is a possibility of altering biochemical pathways during the tissue culture process due to continuous exposure to excessive amounts of plant growth regulators. Thus, comparison of phytochemicals present in rhizomes of natural plants and tissue cultured plants are necessary if the tissue cultured plants are using as alternative to natural plants.

\section{Materials and methods}

For all tissue culture experiments, Murashige and Skoog (MS) medium $^{8}$ was used as the basal medium with $30.0 \mathrm{~g} / \mathrm{L}$ sucrose and jelly moss $(8.0 \mathrm{~g} / \mathrm{L})$ as gelling agent. The $\mathrm{pH}$ of the media was adjusted to 5.8. Unless otherwise stated there were twenty replicates in each treatment. Randomized Block Design (RDB) was used in all experiments and culture bottles were randomized at seven day intervals. Cultures were incubated at $25 \pm 1^{\circ} \mathrm{C}$ in 16 hours photoperiod. Results were analyzed using Minitab statistical package.

\section{In vitro propagation of $K$. galanga from axillary buds}

Shoot induction and multiplication: Rhizomes of $K$. galanga was wrapped in wet tissues and allowed the axillary buds to be elongated. Axillary buds were removed carefully from the rhizome and initially washed in $5 \%$ Clorox $\left(5.25 \% \mathrm{NaOCl}^{\mathrm{TM}}\right)$ for 15 minutes and transferred into laminar flow cabinet. Then they were washed in $10 \%$ Clorox and $70 \%$ ethanol each followed by two successive washings in sterile distilled water before being transferred in to culture media. Explants were cultured on MS medium supplemented with 1.0-3.0mg/L BAP 
(Benzyl amino purine) and 0.2-1.0mg/L IAA (Indole-3-acetic acid). Growth regulator free MS medium was used as the control. Mean number of shoots per axillary bud and the mean shoot length was observed weekly over a period of 4 weeks of incubation.

Root induction of in vitro shoots: For root induction, elongated in vitro shoots $(\geq 3.0 \mathrm{~cm})$ were either continuously sub-cultured in the same medium or separated after 3 weeks and cultured in MS medium supplemented with IBA $(0.0-1.0 \mathrm{mg} / \mathrm{L})$ and $1.0 \mathrm{mg} / \mathrm{L}$ IAA. The jelly moss level was decreased to $7.0 \mathrm{~g} / \mathrm{L}$. Number of roots produced and length of the roots were recorded weekly over a period of 4 weeks.

Acclimatization of tissue cultured plantlets: Rooted plantlets were carefully removed from the medium washed in Luke water to remove all traces of agar. They were dipped in the fungicide solution (Bullet ${ }^{\circledR}$ $2.0 \mathrm{mg} / \mathrm{L}$ ) and acclimatized in a potting mixture of soil: sand: compost $(1: 1: 1)$ or a mixtures of soil: paddy husk (1:1 and $1: 2)$. They were maintained in a mist chamber for 2 weeks and transferred to soil. Percentage survival was assessed after 4 weeks, keeping the plants in an open environment.

\section{Determination of the larvicidal activity in rhizomes of natural and tissue cultured plants of $K$. galanga}

Rhizomes were collected from tissue cultured plants as well as naturally grown plants after 8 months of growth, air dried and ground into powder. Powdered rhizomes ( $100.0 \mathrm{~g}$ each) were separately added to $500 \mathrm{ml}$ of hexane and kept in room temperature for maceration and then suction filtered through a buchner funnel. Filtrate was evaporated by rotary vapour at $40^{\circ} \mathrm{C}$. To obtain methanolic extract, another $100.0 \mathrm{~g}$ of powder from each sample was placed separately each in $500 \mathrm{ml}$ of $85 \%$ methanol for $12 \mathrm{~h}$ in soxhlet apparatus. Crude obtained from hexane and methanol extractions were dissolved in $100.0 \mathrm{ml}$ of distilled water separately to evaluate the larvicidal activity. Aqueous extract was prepared simply by mixing powdered $K$. galang $a$ with $100.0 \mathrm{ml}$ of boiling water and keeping overnight at room temperature. Different concentrations $(10 \%, 25 \%, 50 \%$ and $100 \%)$ of hexane, methanol and water extracts were tested against fourth instar larvae of Aedes aegypti. Larvae (10 in each $100 \mathrm{ml}$ beaker) were placed in $20.0 \mathrm{ml}$ of test solutions. Water was used as the control. Mortality was observed hourly over a period of $24 \mathrm{~h}$. Percentage mortality was calculated using the equation below:

$$
\operatorname{Mortality}(\%)=\frac{X-Y}{X} \times 100
$$

Where,

$\mathrm{X}=$ Percentage survival in the untreated (control) and

$\mathrm{Y}=$ Percentage survival in the test sample.

Mosquito repellent activity of dry rhizome powder of natural and tissue cultured plants of $K$. galanga. Randomly collected adult mosquitoes from different species (A. aegypti, A. albopictus, Culex sp. and Armigerous sp.) were used in this experiment. Test samples for repellent activity were prepared by mixing $K$. galanga powder with starch as a base. $K$. galanga powder along $(1.0 \mathrm{~g}$ or $2.0 \mathrm{~g})$ or a mixture of powder: starch $(0.75 ; 0.25)$ was tested and starch alone was used as the control. The adult mosquitoes (15 in each treatment) were exposed to the prepared test samples during their active hours (5.00$7.00 \mathrm{pm}$ of evening) by placing the test sample mixtures inside net cages $\left(0.5 \times 0.5 \times 0.5 \mathrm{~m}^{3}\right)$. Repellent distance of mosquitoes was scored in every 15 minute intervals using the scale placed inside the cage.

\section{Comparison of phytochemicals present in rhizomes of natural and tissue cultured plants of $K$. galanga}

Dry rhizomes of $K$. galanga from natural and tissue cultured plants $(10.0 \mathrm{~g}$ each) were powdered and separately extracted with $250.0 \mathrm{ml}$ of Hexane using the soxhlet apparatus for 3hours. Then the Hexane extract was concentrated to $1.0-2.0 \mathrm{ml}$ by evaporating in rotary evaporator (BUCHI-R-124). Concentrated extracts were subjected to GC-MS analysis. Chromatograms were observed and the chemical constituents present in the sample were identified.

\section{Results and discussion}

\section{In vitro propagation of $K$. galanga from axillary buds}

Shoot induction and multiplication: In vitro axillary bud elongation was observed after 2 weeks of incubation (Figure 1) in all tested media. MS medium supplemented with $2.0 \mathrm{mg} / \mathrm{L}$ BAP and $0.5 \mathrm{mg} / \mathrm{L}$ IAA showed the highest elongation $(214.90 \pm 0.10 \mathrm{~cm})$ as well as the highest multiplication rate $(12.0 \pm 0.02)$. Increased BAP concentration $(3.0 \mathrm{mg} / \mathrm{L})$ with $0.5 \mathrm{mg} / \mathrm{L}$ IAA decreased the elongation of shoots $(2.25 \pm 0.21)$ as well as multiplication rate $(3.0 \pm 0.10)$ after 4 weeks of incubation Growth regulator free MS medium (control) showed low response in multiplication as well as elongation of in vitro shoots (Table 1). In vitro shoot induction in MS medium supplemented with BAP $(0.3 \mathrm{mg} / \mathrm{L})$ and IBA $(0.15 \mathrm{mg} / \mathrm{L})^{9}$ and IBA $(2.7 \mathrm{mg} / \mathrm{L})$ and NAA $(0.55 \mathrm{mg} / \mathrm{L})^{10}$ has been reported. In some of the studies Kin (Kinetin) also has been used to induce shoots in vitro. It has been reported that the highest multiplication rate $(8.2 \pm 0.21)$ in the medium supplemented with $3.0 \mathrm{mg} / \mathrm{L} \mathrm{BAP}$ and $4.0 \mathrm{mg} / \mathrm{L} \mathrm{Kin}^{11}$ and multiple shoot induction in MS medium supplemented with IBA $\left(0.49 \mathrm{mg} / \mathrm{L}\right.$, Kin $(2.99 \mathrm{mg} / \mathrm{L})^{12}$ is also reported. However the multiplication rates reported in all those studies were lower than that the of present study indicating that MS medium supplemented with $2.0 \mathrm{mg} / \mathrm{L}$ BAP and $0.5 \mathrm{mg} / \mathrm{L} \mathrm{IAA}$ is a better medium for elongation and multiplication of $K$. galanga.

Root induction of in vitro shoots: In vitro propagated shoots transferred to shoot induction media induced roots; however root induction took longer period (10 weeks). Root induction in shoot multiplication medium was reported. ${ }^{10,12}$ IAA alone did not induce roots. The best growth regulator combination for in vitro root induction found to be MS medium supplemented with $0.2 \mathrm{mg} / \mathrm{L}$ IBA and $1.0 \mathrm{mg} / \mathrm{L}$ IAA with a mean of $6.0 \pm 0.12$ roots $/$ shoot and $39.8 \pm 1.11 \mathrm{~mm}$ length. Increasing concentrations of IBA drastically reduced the root induction as well as root elongation (Table 2). Roots were initiated in MS medium with $0.4 \mathrm{mg} / \mathrm{L}$ BAP and $0.2 \mathrm{mg} / \mathrm{L}$ IBA after further incubation for 12 weeks ${ }^{9}$ indicating that IBA plays an important role in root induction in $K$. galanga.

Acclimatization of tissue cultured plantlets: Highest percentage of survival $(100 \%)$ was observed when tissue cultured plantlets were acclimatized in soil: sand: compost (1:1:1). When in vitro plantlets were grown in the mixture of soil: paddy husk (1:1) $80 \%$ survival was observed. Soil: paddy husk (1:2) mixture showed lowest survival rate $(30 \%)$. Reduction of water holding capacity in the presence of high amount of paddy husk in this treatment could be the reason for low survival percentage of plantlets in this potting mixture. Use of porous potting mixture with good water holding capacity which allows adequate drainage and aeration would provide better conditions for fast acclimatization of in vitro regenerated plants. 
Table I Mean shoot elongation and mean number of shoots/explant in different tested media after 4 weeks of incubation

\begin{tabular}{llll}
\hline \multicolumn{2}{l}{ Growth regulator combination $(\mathbf{m g} / \mathbf{L})$} & Mean no of shoot/explant \pm SE & Mean shoot length $(\mathbf{m m}) \pm$ SE \\
\hline BAP & IAA & $1.0 \pm 0.12$ & $3.55 \pm 1.65$ \\
\hline Control & 0 & $3.0 \pm 0.30$ & $5.38 \pm 0.11$ \\
1 & 0.5 & $7.0 \pm 0.02$ & $9.21 \pm 0.11$ \\
I & 1 & $4.2 \pm 0.10$ & $6.62 \pm 0.12$ \\
1 & 0 & $2.5 \pm 0.40$ & $6.23 \pm 015$ \\
2 & 0.5 & $12.0 \pm 0.02$ & $14.90 \pm 0.10$ \\
2 & 1 & $9.60 \pm 0.09$ & $11.91 \pm 0.20$ \\
2 & 0 & $2.0 \pm 0.20$ & $2.11 \pm 0.11$ \\
3 & 0.5 & $4.0 \pm 0.50$ & $3.00 \pm 0.09$ \\
3 & 1 & $3.0 \pm 0.10$ & $2.25 \pm 0.21$ \\
3 & 0.11 & 0.18 \\
\hline LSD 5\% & & & \\
\hline
\end{tabular}
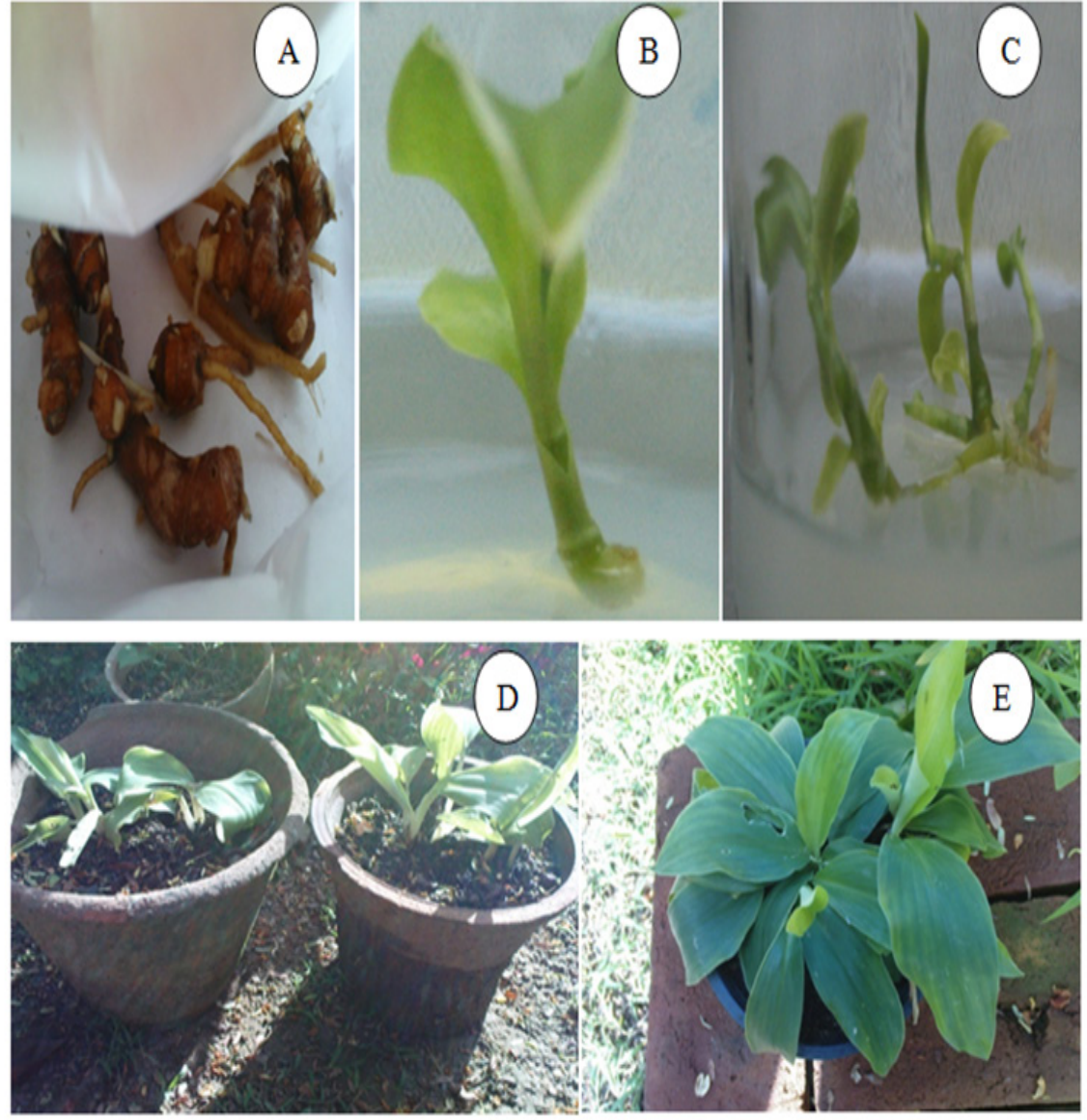

Figure I
A. Axillary bud induction from rhizomes
B. Elongated shoots
C. Multiple shoot shoots and root induction
D. Acclimatized plants and
E. Growth of tissue cultured plants after 8 weeks.

Citation: Senarath RMUS, Karunarathna BMAC, Senarath WTPSK, et al. In vitro propagation of Kaempferia Galanga (zingiberaceae) and comparison of larvicidal activity and phytochemical identities of rhizomes of tissue cultured and naturally grown plants. J Appl Biotechnol Bioeng. 2017;2(4):I57-162. DOI: 10.15406/jabb.2017.02.00040 


\section{Determination of the larvicidal activity in rhizomes of natural and tissue cultured plants of $K$. galanga}

Percentage mortality of the mosquito larvae after 24 hours incubation in different extracts are summarized in Table 3. From the results obtained observed it was observed that the larvicidal activity against fourth instar larvae of $A$. aegyptii is comparatively higher in tissue cultured plants than that of naturally grown plants. Hexane extracts found to be the best against larvicidal activity and methanol and aqueous extracts showed lower activity against mosquito larvae tested (Table 3). In the present study it revealed that maximum mortality rate that could be obtained was only $10 \%$ which is very low, still there is a potential of using $K$. galanga as a larvicide if extraction procedures are improved. Hexane extract effectively kills larvae of the mosquito Culex quinquefasciatus and repels adult $A$. aegypti mosquitoes, both of which are serious disease vectors ${ }^{13}$ which

Table 2 Mean no. of roots and mean root length in MS medium supplemented I.0mg/L IAA and different IBA $(0.0-1.0 \mathrm{mg} / \mathrm{L})$ concentrations after 4 weeks of incubation is comparable with the results of the present study. The toxicity of ethyl cinnamate and ethyl p-methoxycinnamate (EMC) identified in $K$. galanga rhizome and another 12 known compounds to thirdinstar larvae from laboratory-reared C. pipiens pallens Forskal, A. aegypti was tested and found that this could be used as a potential mosquito control agents for protection of humans. ${ }^{14}$ Kaempferol is a natural flavonol, a type of flavonoid and is slightly soluble in water, but soluble in hot ethanol and diethyl ether ${ }^{15}$ confirming the results of the present study in which aqueous extract demonstrated lowest percentage mortality. However in the present study it was observed that the phytochemical constituents present in tissue cultured plants are comparatively higher than those of natural plants confirming that tissue culture protocol could be an alternative propagation method for mass cultivation of $K$. galanga to obtain rhizomes with high amount of secondary metabolites.

\begin{tabular}{|c|c|c|}
\hline IBA concentration (mg/L) & Mean no. of roots/shoot & Mean root length $(\mathrm{mm})$ \\
\hline 0.0 (Control) & 0 & 0 \\
\hline 0.2 & $6.0 \pm 0.12$ & $39.8 \pm 1.11$ \\
\hline 0.4 & $3.1 \pm 0.10$ & $12.8 \pm 0.99$ \\
\hline 0.6 & $2.2 \pm 0.11$ & $10.1 \pm 1.00$ \\
\hline 0.8 & $I . I \pm 0.11$ & $6.2 \pm 1.01$ \\
\hline I & $1.0 \pm 0.13$ & $5.2 \pm 1.13$ \\
\hline LSD 5\% & 0.01 & 0.03 \\
\hline
\end{tabular}

Table 3 Percentage mortality of mosquito larvae after 24 hours in different concentration of hexane, methanol and aqueous extracts of K. galanga

\begin{tabular}{llllllllll}
\hline \multirow{2}{*}{ Extract } & \multicolumn{7}{c}{ Tissue cultured plants } & \multicolumn{7}{c}{ Natural plants } \\
\cline { 2 - 9 } & $10 \%$ & $\mathbf{2 5 \%}$ & $\mathbf{5 0 \%}$ & $\mathbf{1 0 0 \%}$ & $\mathbf{1 0 \%}$ & $\mathbf{2 5 \%}$ & $\mathbf{5 0 \%}$ & $\mathbf{1 0 0 \%}$ \\
\hline Control (Water) & 0 & 0 & 0 & 0 & 0 & 0 & 0 & 0 \\
Aqueous & 0 & 1 & 4 & 6 & 0 & 0 & 3 & 5 \\
Methanol & 4 & 6 & 9 & 10 & 4 & 5 & 6 & 8 \\
Hexane & 5 & 8 & 10 & 10 & 5 & 7 & 7 & 9
\end{tabular}

\section{Mosquito repellent activity of dry rhizome powder of natural and tissue cultured plants of $K$. galanga}

When adult mosquitoes were tested against repellent activity, although $K$. galanga rhizome powder does not kill the adult mosquitoes, their mobility has been affected. They rest on the net of the cage after 25-30 minutes (Figure 2A \& 2B). Extracts of $K$. galanga causes central nervous system depression, a decrease in motor activity and a decrease in respiratory rate. ${ }^{15}$ When the rhizome powder from natural plants and tissue cultured plants alone was tested in two concentrations for mosquito repellent activity, the mobility for naturally grown plants showed the distance of $24.16 \pm 0.94$, $28.31 \pm 1.25$ while tissue cultured plants showed mosquito harboring in $32.49 \pm 0.5,31.54 \pm 0.54$ distance respectively for $1.0 \mathrm{~g}$ and $2.0 \mathrm{~g}$. No significant different was observed when the dry rhizome powder used as a mixture $(0.75: 0.25)$ or along $(1.0 \mathrm{~g})$ indicating the use of low amount of rhizome powder is also possible to repel the mosquitoes. Literature survey revealed that there are very less reports on neuro pharmacological activity of this plant. In the sedative activity study, extracts exhibited significant reduction of locomotor and exploratory activities in Swiss albino mice. Results of the study with Swiss albino mice indicated that all tested doses $(100$ and $200 \mathrm{mg} / \mathrm{kg})$ of different extracts of $K$. galanga exhibited significant sedative effect. The effect is dose dependent, long lasting and statistically significant. ${ }^{15}$ Hexane extract of the rhizome has been used to test the mosquito repellent activity. ${ }^{16}$ The results of this preliminary study could be used in 
developing a commercial herbal powder to use as a mosquito repellent for mosquito species namely-A.aegypti, A. albopictus, Culex sp. and Armigerous sp.-using a suitable base instead of starch which is more convenient and cost effective.

\section{Comparison of phytochemicals present in rhizomes of natural and tissue cultured plants of $K$. galanga}

Total of thirteen compounds were identified from the dry rhizome sample of natural plants (Figure 3A) and many of the compounds showed the similarity of more than $90 \%$ except Cyclopentane in which the similarity was only 58\%. From the GC-MS analysis on hexane extract total of eleven compounds were identified from the dry rhizome sample of tissue cultured plants (Figure 3B). All the compounds present in rhizome sample of tissue cultured $K$. galanga showed over $90 \%$ similarity, however, $p$-Hydroxycinnamic acid, ethyl ester has the similarity of $78 \%$ which is comparatively lower than the similarity of other compounds. It was observed that nine similar major compounds are common to both natural and tissue cultured rhizome samples. Except Borneol, all the other phytochemical identities showed more or less similarities. Presence of Borneol in natural plants showed $95 \%$ similarity, while it was $90 \%$ in tissue cultured plants (Table 4). This further proves the potential of using of rhizomes of tissue cultured plants as the substitute for rhizomes of natural plants in pharmaceutical industry.

Table 4 Comparison of phytochemicals presents in rhizomes of natural plants and tissue cultured plants

\begin{tabular}{llll}
\hline \multirow{2}{*}{ Compound } & Molecular weight $\mathbf{( g / m o l})$ & \% Similarity & \\
\cline { 3 - 4 } Decane & 142 & Natural & Tissue cultured \\
3-Carene & 136 & 95 & 95 \\
Eucalyptol & 124 & 97 & 96 \\
Borneol & 154 & 98 & 99 \\
Dodecane & 170 & 95 & 90 \\
2-propenoic acid, 3-phenyl-,ethyl ester (Ethylcinnamate) & 176 & 96 & 96 \\
Pentadecane & 212 & 96 & 96 \\
2-propenoic acid & 201 & 96 & 96 \\
Heptadecenal & 252 & 99 & 99 \\
\hline
\end{tabular}
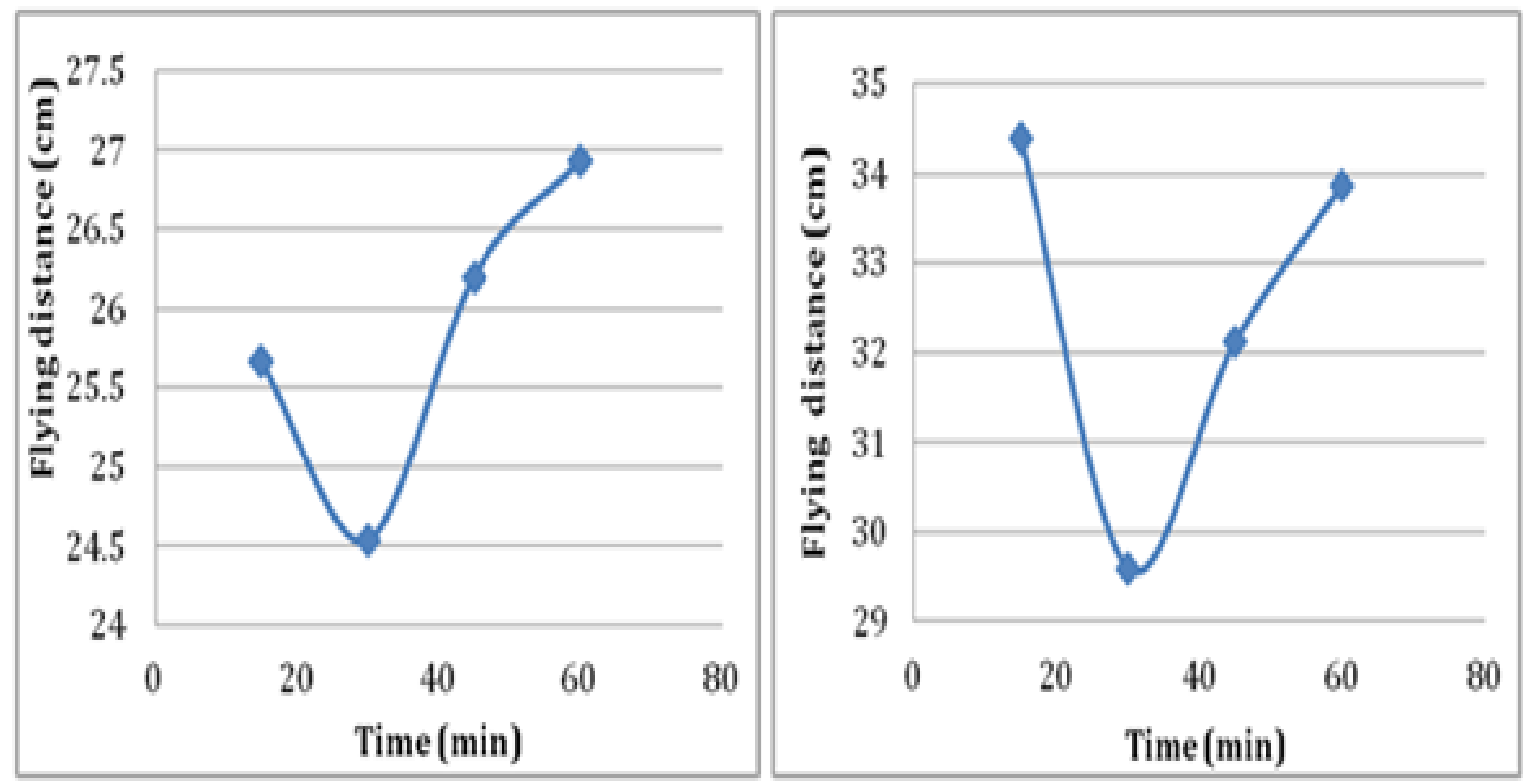

Figure 2 Flying distance of mosquitoes versus time for dry rhizome powder (sample: starch $0.75: 0.25$ ) of
A. Natural plant and
B. Tissue cultured plant.

Citation: Senarath RMUS, Karunarathna BMAC, Senarath WTPSK, et al. In vitro propagation of Kaempferia Galanga (zingiberaceae) and comparison of larvicidal activity and phytochemical identities of rhizomes of tissue cultured and naturally grown plants. J Appl Biotechnol Bioeng. 2017;2(4):I57-162. 

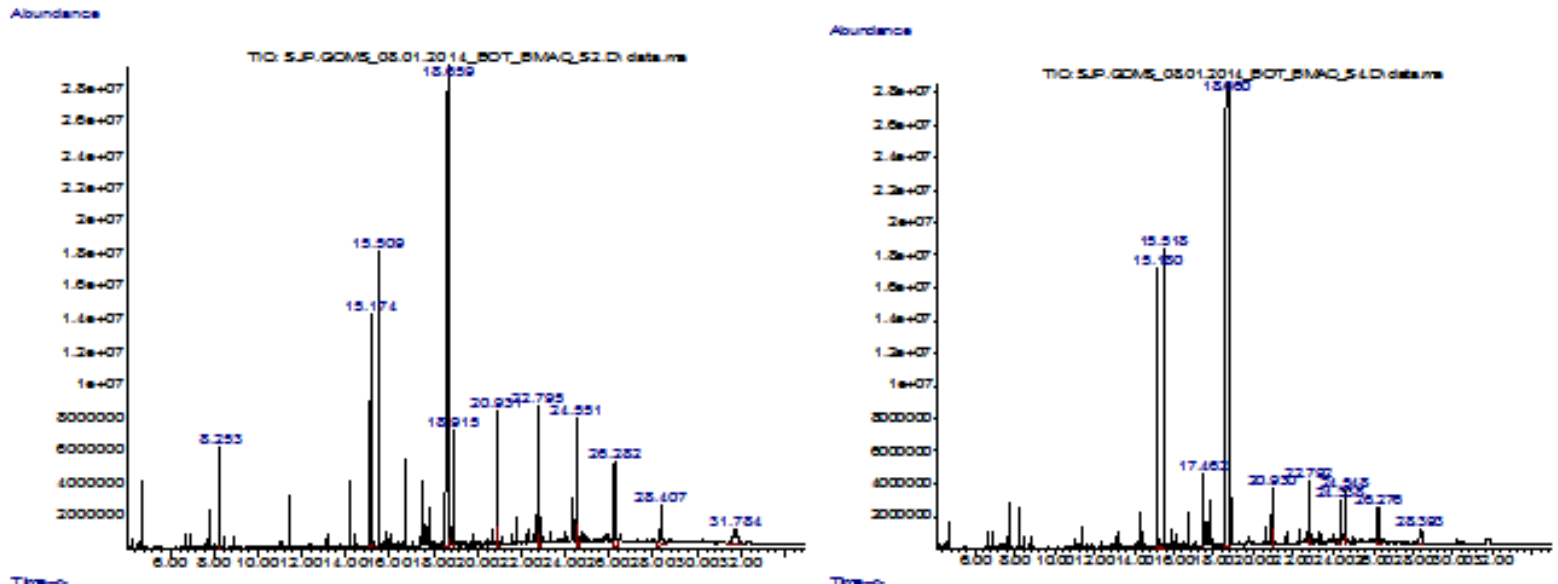

Figure 3 GC-MS chromatogram of the rhizome of

A. Natural plants and

B. Tissue cultured plants.

\section{Conclusion}

The tissue culture protocol developed in the present study could be used as an alternative for vegetative propagation methods for mass propagation and conservation of the $K$. galanga as phytochemicals present in tissue cultured plants found to be similar to natural plants. And also the quantity of important phytochemicals in tissue cultured plants found to be higher indicating that the use of tissue culture protocol developed would be beneficial in obtaining plants with high quantity of phytochemicals.

\section{Acknowledgements}

None.

\section{Conflict of interest}

The author declares no conflict of interest.

\section{References}

1. Sala AV. Indian medicinal plant. India: Orient Longman Ltd; 1995;3:274-275.

2. Ibemhal A, Laishram JM, Dhananjoy $\mathrm{CH}$, et al. In vitro induction of multiple shoot and root from the rhizome of Kaempferia galanga L. Nebio J of Env and Biodi. 2012;3(3):46-50.

3. Wong KC, Ong KS, Lim CL. Composition of the essential oil of rhizome of Kaempferia galanga (L). Flavour Fragr J. 1992;7(5):263-266.

4. Arambewela L, Silva R. Sri Lankan medicinal plant monographs and analysis. J of Nat Sci Foun. 1999;1:5-21.

5. Ghani A. Medicinal plants of Bangladesh: Chemical constituents and use. Bangladesh: Asiatic Society of Bangladesh; 1998. 467 p.

6. Rahman MM, Amin MN, Ahamed T, et al. Efficient plant regeneration through somatic embryogenesis from leaf base-derived callus of Kaemferia galanga L. Asian J Plant Sci. 2004;3(6):675-678.

7. Kuen TG, Khaladalla MM, Bhatt A, et al. Callus induction and cell line establishment from various explants of Kaempferia galanga. International Journal of Current Research. 2011;3(12):1-4.

8. Murashige T, Skoog F. A revised medium for rapid growth and bioassays with tobacco tissue culture. Physiologia Plantarum. 1962;15(3):473479 .

9. Hettiarachchi A, Mendis MH, Ganeshan P, et al. Micropropagation of some medicinal plants of Sri Lanka. Proceedings of seminar held on $28^{\text {th }}$ and $29^{\text {th }}$ March 1994 at Plant Genetic Resource Centre, Gannoruwa, Sri Lanka; 1994. p. 59-65.

10. Shirin F, Kumar S, Mishra Y. In vitro plantlet production system for Kaempferia galanga. Plant Cell, Tissue and Organ Culture. 2000;63(3):193197.

11. Bhattacharya M. In vitro regeneration of pathogen free Kaempferia galanga L:A rare medicinal plant. Res in Plant Bio. 2013;3(3):24-30.

12. Vincent KA, Mathew KM, Hariharan M. Micropropagation of Kaempferia galanga L-a medicinal plant. Plant Cell Tiss Organ Cult. 1992;28(2):229-230.

13. Kanjanapothi D, Panthong A, Lertprasertsuke N, et al. Toxicity of crude rhizome extract of Kaempferia galanga L (Proh Hom). J Ethnopharmacol. 2004;90(2-3):359-365.

14. Kim NJ, Byun SG, Cho JE, et al. Larvicidal activity of Kaempferia galanga rhizome phenylpropanoids towards three mosquito species. Pest Manag Sci. 2008;64(8):857-862.

15. Ali MS, Ranjan Dash P, Nasrin M. Study of sedative activity of different extracts of Kaempferia galanga in Swiss albino mice. BMC Complementary and Alternative Medicine. 2015;15:158-165.

16. Choochote W. Evidence to support karyotypic variation of the mosquito, Anopheles peditaeniatus in Thailand. J Insect Sci. 2011;11:10. 